\title{
C.I. Шоріков \\ ВПРОВАДЖЕННЯ ДОНАТОРІВ ОКСИДУ АЗОТУ В УМОВАХ ГІПЕРТОНІЧНОЇ ХВОРОБИ ЗА ПОСДНАНОГО ПЕРЕБІГУ 3 ЦУКРОВИМ ДІАБЕТОМ 2-ГО ТИПУ 3 УРАХУВАННЯМ АГРЕГАЦІЙНИХ ВЛАСТИВОСТЕЙ ТРОМБОЦИТІВ
}

Вищий державний навчальний заклад України «Буковинський державний медичний університет», м. Чернівці

\begin{abstract}
Резюме. Стаття присвячена вивченню агрегаційних властивостей тромбоцитів у хворих на гіпертонічну хворобу за поєднаного перебігу з цукровим діабетом 2го типу при додаванні до базисного лікування донатора оксиду азоту L-аргініну. Проведено відкрите проспективне дослідження з обстеженням 191 хворого. Встановлено вірогідно більш суттєве зниження параметрів тромбоцитарної агрегації в групі, яка отримувала L-аргінін додатково до базисного лікування. Використання донатора оксиду азоту разом із базисною терапі-
\end{abstract}

Вступ. Важливою ланкою розвитку гіпертонічної хвороби (ГХ) та вагомим фактором ризику цукрового діабету (ЦД) є порушення функції ендотелію $з$ дисфункцією в циклі оксиду азоту. Оксид азоту (NO) - найпотужніший із відомих ендогенних вазодилататорів. Доведено, що при ГХ знижується чутливість артерій до напруги зсуву та продукція NO [8]. Окрім того, при ГХ за поєднаного перебігу з ЦД 2-го типу знижується синтез ендотеліального NO, який утворюється завдяки активності NO-синтази (NOS). Функція оксиду азоту перебуває під постійним модулюючим впливом супероксиду та пероксиду водню, протидіючих ефекту NO [3]. Також доведено, що при ГХ за поєднаного перебігу з ЦД у судинах відбувається додаткова експресія молекул основного джерела супероксиду - NAD(P)Н-оксидази у відповідь на надлишковий синтез ангіотензину II (AT II).

Також при ГХ неодноразово вказувалось на гіперреактивність тромбоцитів, причому іiі ступінь тим вище, чим вище рівень АТ. NO - один із провідних регуляторних біоефекторів процесу агрегації, ключова ланка гуанілатциклазної месенджерної системи [8]. Він підсилює активність гуанілатциклази, що призводить до збільшення змісту циклічного ГМФ і зниженню рівня внутрішньоклітинного $\mathrm{Ca}^{2+}$, внаслідок чого здійснюється контроль над агрегацією тромбоцитів і опосередковується сигнал до дезагрегації [9].

Утворюється оксид азоту з L-аргініну за участі NO-синтази, яка міститься переважно в клітинах ендотелію (NO-синтаза III), іншим продуктом реакції $\epsilon$ L-цитрулін [1]. Тивортин є метаболічним препаратом, де амінокислота L-аргінін виступає основною діючою складовою аргінін, тому даний препарат можна вважати донатором оксиду азоту[2].

Мета дослідження. Дослідити вплив донатора оксиду азоту L-аргініну на стан судиннотромбоцитарного гемостазу у хворих на гіперто- єю супроводжувалося вірогідно більшим подовженням часу АДФ-індукованої та адреналін-стимульованої агрегації, а також більш значному зниженню ступеня АДФ-індукованої та колаген-індукованої агрегації, ніж застосування стандартного антигіпертензивного лікування.

Ключові слова: гіпертонічна хвороба, цукровий діабет, агрегація тромбоцитів, донатор оксиду азоту, $\mathrm{L}$-аргінін.

нічну хворобу за поєднаного перебігу з цукровим діабетом 2-го типу.

Матеріал і методи. Для досягнення поставленої мети було проведено проспективне контрольоване рандомізоване дослідженння. Обстежений 191 пацієнт з ГХ за поєднаного перебігу 3 ЦД 2-го типу. Верифікацію діагнозу з визначенням стадії артеріальної гіпертензії проводили 3 використанням критеріїв, рекомендованих Українською асоціацією кардіологів та Європейським товариством гіпертензії та кардіології [6] та Європейською асоціацією 3 вивчення цукрового діабету [5]. Критеріями виключення були - декомпенсований перебіг цукрового діабету, наявність серцевої недостатності IV функціонального класу, хвороби печінки, онкологічні захворювання та захворювання крові.

Для дослідження агрегаційних властивостей тромбоцитів проводився забір крові вранці, натще, $з$ ліктьової вени, як стабілізатор використовувався 3,8 \% розчин цитрату натрію. Аналіз параметрів тромбоцитарного гемостазу проводився на аналізаторі агрегації тромбоцитів АР-2110 (Solar, Бєларусь) турбідиметричним методом за J. Born. При додаванні АДФ у концентрації 1,25 мкмоль/л визначали показники АДФ-індукованої агрегації тромбоцитів: ступінь агрегації (\%), час агрегації (c), швидкість агрегації (\%/хв) з автоматичною побудовою кривих-агрегатограм. Колаген-індукована агрегація досліджувалася після додавання колагену в концентрації 1 мг/мл, параметри адреналін-індукованої агрегації - $з$ використанням адреналіну 2,5 мкмоль/л.

Донатор оксиду азоту тивортин (L-аргінін) призначався внутрішньовенно на фоні базисної антигіпертензивної (іАПФ+антагоніст кальцію) та цукрознижуючої терапії. Доза препарату була стандартною для всіх досліджуваних хворих i складала 4,2 г (4,2\% 100 мл) в/в 1 раз на добу впродовж двох тижнів стаціонарного лікування. Порівняння проводилося між хворими, що отри- 
мували тільки базисну терапію (група 1 - 85 осіб) та хворими, які на тлі базисної терапії додатково приймали L-аргінін (група 2 - 106 осіб). У процесі лікування препарат відмінили чотирьом хворим $(3,77 \%)$ внаслідок появи вираженого головного болю (3 особи, 2,83 \%) та нудоти (1 особа, $0,94 \%$ ) під час уведення препарату.

Для статистичного аналізу отриманих результатів використовували пакет програм обробки даних загального призначення Statistica for Windows версії 7.0 (Stat Soft inc., США). Статистичну різницю оцінювали за допомогою парного та звичайного t-критеріїв Стьюдента для зв'язаних та незалежних даних. При $\mathrm{p}<0,05$ різницю вважали статистично вірогідною.

Дослідження проведено у відповідності до Гельсінської декларації 1975 р.

Результати дослідження та їх обговорення. За аналізу параметрів індукованої агрегації тромбоцитів встановлено вірогідне зниження показників як у групі 1, так і у групі 2, при цьому АДФіндукована агрегація знизилася на 12,0 \% (група 1 - $350,8 \pm 14,3$ до $38,8 \pm 12,1, \mathrm{p}<0,05)$ та $34,7 \%$ (група 2 - $з$ 62,8 $\pm 18,9$ до $28,1 \pm 10,3, \mathrm{p}<0,05$ ), адреналін-індукована агрегація - на $22,1 \%$ у групі 1 (3 $50,5 \pm 14,1$ до $28,4 \pm 16,2)$ та $26,9 \%$ у групі 2 (3 $59,2 \pm 17,7$ до $32,3 \pm 13,5, \quad \mathrm{p}<0,05)$, колагеніндукована агрегація зменшилась на 17,3\% (3 $53,6 \pm 12,5$ до $36,3 \pm 8,2, \quad \mathrm{p}<0,05)$ та $26,7 \%$ (3 $58,2 \pm 14,1$ до $31,5 \pm 14,4, \mathrm{p}<0,05)$ відповідно, рис. 1 .

Слід також відмітити, що за додавання метаболічної терапії $з$ використанням донатора оксиду азоту L-аргініну спостерігалося вірогідно більш значне зниження АДФ-індукованої $\left(\mathrm{p}_{1}<0,05\right)$ та колаген індукованої агрегації $\left(\mathrm{p}_{1}<0,05\right)$ щодо групи, в якій використовувалася тільки стандартна антигіпертензивна терапія.

Також у власному дослідженні встановлено подовження часу АДФ-індукованої агрегації в групі базисного лікування на 21,8 \% (з 96,2 $\pm 31,2$ до $117,2 \pm 27,2$ с) та в групі з додатковим призна-

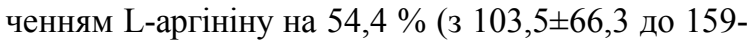

$, 8 \pm 21,6$ с), часу адреналін-індукованої агрегації в групі 1 на 29,0 \% (зі 105,1 $\pm 28,1$ до $135,6 \pm 26,1)$ та групі 2 на 71,7 \% (з 94,6 222,7 до $162,4 \pm 28,0$ c), часу колаген-індукованої агрегації на 22,4 \% (3 $95,8 \pm 36,2$ до $117,3 \pm 27,6, \mathrm{p}<0,05)$ та $65,5 \%$ (з 89$89,0 \pm 39,8$ до 147,3 $\pm 39,4$ с., $\mathrm{p}<0,05$ ), (рис. 2).

Як бачимо, за аналізу показників АДФіндукованої та адреналін-стимульованої агрегації, призначення донатора оксиду азоту у хворих на ГХ за поєднаного перебігу з ЦД 2-го типу супроводжувалося більш значним подовженням часу АДФ-індукованої $\left(\mathrm{p}_{1}<0,05\right)$ та адреналініндукованої агрегації $\left(\mathrm{p}_{1}<0,05\right)$, порівняно 3 ізольованим базисним лікуванням (рис. 2).

Швидкість АДФ-індукованої агрегації на тлі застосування базисного лікування знижувалася на $67,0 \%$ ( $343,6 \pm 10,2$ до $26,1 \pm 9,83 \% / x в, p<0,05$ ), адреналін-індукованої агрегації - на 75,9 \% (3 $24,1 \pm 13,2$ до $13,7 \pm 5,71 \% / \mathrm{xв}, \mathrm{p}<0,05)$, колаген-

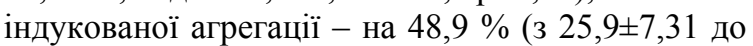
$17,4 \pm 5,41 \% / \mathrm{xB}, \mathrm{p}<0,05)$. На тлі додаткового призначення L-аргініну швидкість АДФстимульованої агрегації тромбоцитів зменшувалася на $66,9 \%$ (з 42,9 $\pm 12,4$ до $25,7 \pm 13,1 \% /$ хв, $\mathrm{p}<0,05)$, адреналін-стимульованої агрегації - на $94,9 \%$ (з 30,4 $\pm 10,8$ до $15,6 \pm 7,17 \% / \mathrm{xв,}<<0,05$ ), колаген-стимульованої - на 55,7 \% (з 24,6 45,53 до $15,8 \pm 3,49 \% / \mathrm{xв}, \mathrm{p}<0,05$ ), (рис. 3 ).

Таким чином, застосування донатора оксиду азоту L-аргініну має досить велике значення в профілактиці та лікуванні гіпертонічної хвороби за поєднаного перебігу з цукровим діабетом. Оксид азоту гальмує адгезію та агрегацію тромбоцитів, прогресування тромбоутворення [4].

У ході чисельних клінічних досліджень доведено, що призначення L-аргініну при таких нозологіях, як артеріальна гіпертензія, ішемічна хвороба серця, цукровий діабет може покращувати клінічний перебіг і прогноз захворювання [10]. Li Q., Youn J. Y. та співавт. представили результати досліджень, присв'ячених вивченню ефектів оксиду азоту на функціональний стан ендотелію [7].

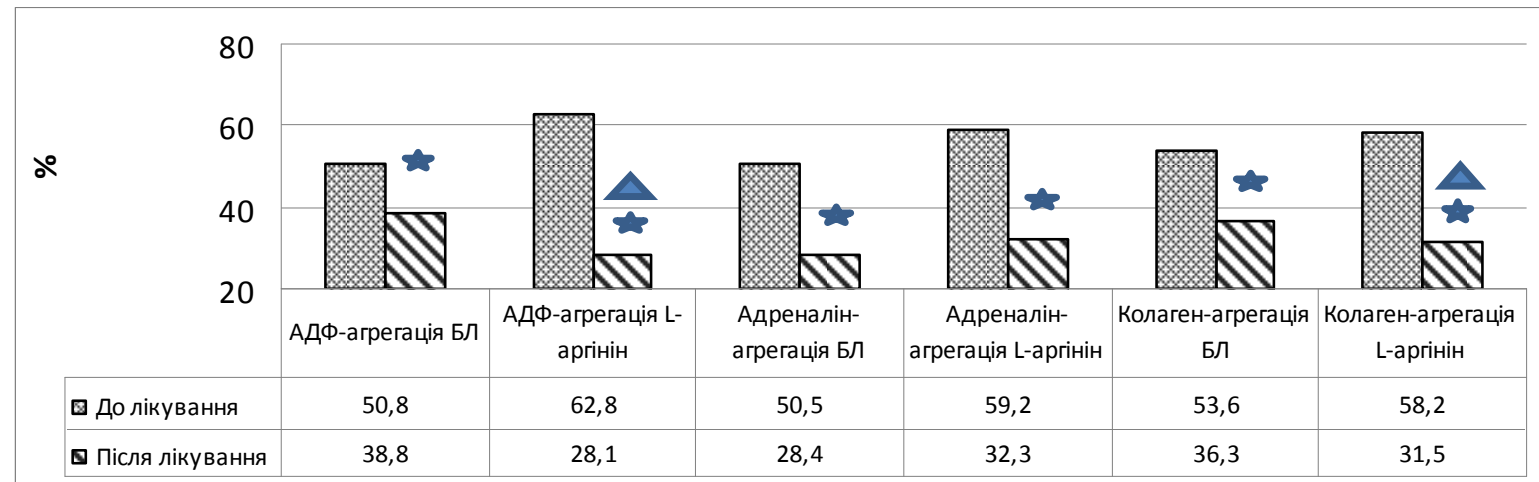

Рис. 1. Індукована агрегація тромбоцитів у хворих на гіпертонічну хворобу за поєднаного перебігу з цукровим діабетом 2-го типу в динаміці лікування

1

вірогідність різниці показників у динаміці лікування;

вірогідність різниці показників після лікування в групах 1 та 2 


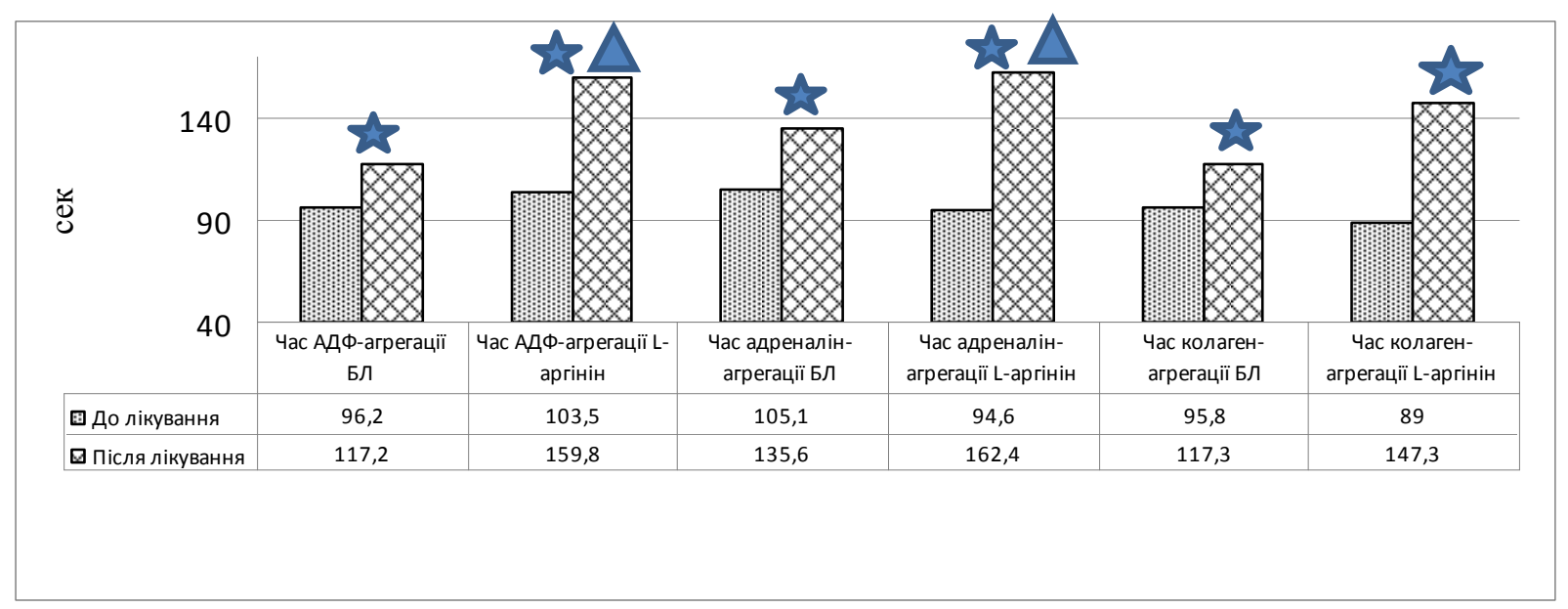

Рис. 2. Час агрегації тромбоцитів у хворих на гіпертонічну хворобу за поєднаного перебігу з цукровим діабетом 2-го типу в динаміці лікування.

2 вірогідність різниці показників у динаміці лікування;

вірогідність різниці показників після лікування в групах 1 та 2

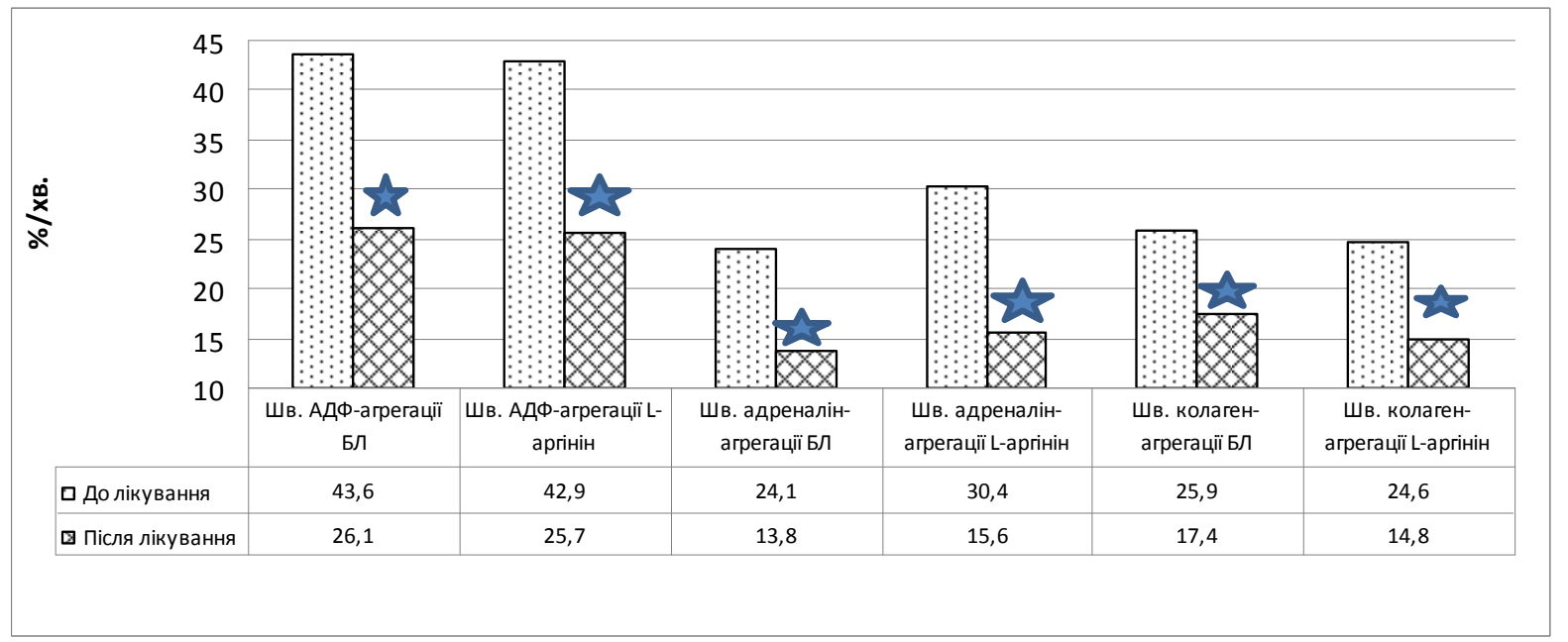

Рис. 3. Швидкість агрегації тромбоцитів у хворих на гіпертонічну хворобу за поєднаного перебігу з цукровим діабетом 2-го типу в динаміці лікування

вірогідність різниці показників у динаміці лікування;

вірогідність різниці показників після лікування в групах 1 та 2

У власному дослідженні, за оцінки стану ендотеліально-судинного гемостазу у хворих на артеріальну гіпертензію за поєднаного перебігу 3 цукровим діабетом 2-го типу, отримані результати, що доводять вірогідне посилення ефективності базисного лікування щодо агрегаційних властивостей тромбоцитів при додаванні донатора оксиду азоту L-аргініну.

\section{Висновки}

1. При використанні донаторів оксиду азоту у хворих на гіпертонічну хворобу за поєднаного перебігу з цукровим діабетом 2-го типу спостерігається позитивний вплив на показники судиннотромбоцитарного гемостазу.

2. Встановлено вірогідно більш суттєве зниження параметрів спонтанної агрегації в групі, яка отримувала донатор оксиду азоту додатково до базисного лікування.
3. Ступінь зниження АДФ-індукованої та колаген індукованої агрегації був вірогідно більш значним при комплексному лікуванні з використанням донатора оксиду азоту, ніж при стандартній антигіпертензивній терапії.

4. Використання донатора оксиду азоту разом із базисною терапією супроводжувалося вірогідно більшим подовженням часу АДФіндукованої та адреналін-стимульованої агрегації у хворих на гіпертонічну хворобу з цукровим діабетом 2-го типу, ніж застосування тільки базисної терапії.

Перспективи подальших досліджень. У перспективі $є$ актуальним вивчення ефективності донатора оксиду азоту відносно інших прогностичних показників, вплив на первинні та вторинні серцево-судинні події у хворих на гіпертонічну хворобу за поєднаного перебігу з цукровим діабетом 2-го типу. 


\section{Література}

1. Значение дисфункции эндотелия при сердечнососудистых заболеваниях и методы ее медикаментозной коррекции / Н.Ш. Загидуллин, К.Ф. Валеева, Н. Гассанов [и др.] // Кардиология. - 2010. - Т. 50, № 5. - C. 54-60

2. Значення L-аргініну в лікуванні хворих із серцевосудинною патологією / М.І. Лутай, В.В. Бугаєнко, O.I. Моїсеєнко [та ін.] // Укр. кардіол. ж. - 2011. № 4. - C. 96-107.

3. Association between hypertriglyceridemia and protein oxidation and proinflammatory markers in normocholesterolemic and hypercholesterolemic individuals / J.Z. Klafke, F.G. Porto, R. Batista [et al.] // Clin. Chim. Acta. 2015. - Vol. 448. - P. 50-57.

4. Circulating miR-21 and eNOS in subclinical atherosclerosis in patients with hypertension / M. Cengiz M, S. Yavuzer, A. B. Kiliçkiran [et al.] // Clin. Exp. Hypertens. 2015. - Vol. 26. - P. 1-7.

5. ESC Guidelines on diabetes, pre-diabetes, and cardiovascular diseases developed in collaboration with the EASD /
L. Ryden, P.J. Grant, S.D. Anker [et al.] // Eur. Heart J. 2013. - Vol. 34. - P. 3035-3087.

6. ESH/ESC Guidelines for the management of arterial hypertension / G. Mancia, R. Fagard, Kr. Narkiewicz [et al.] // Eur. Heart J. - 2013. - Vol. 34. - P. 2159-2219.

7. Mechanisms and consequences of endothelial nitric oxide synthase dysfunction in hypertension / Q. Li, J.Y. Youn, H. Cai // J. Hypertens. - 2015. - Vol. 33, № 6. P. $1128-1136$

8. Mokhtar S. S. Role of endothelium-dependent hyperpolarisation and prostacyclin in diabetes / S.S. Mokhtar, A.H. Rasool // Malays. J. Med. Sci. - 2015. - Vol. 22, № 2. - P. 8-17.

9. Nitrate pharmacokinetics: Taking note of the difference / P.E. James, G.R. Willis, J.D. Allen [et al.] // Nitric Oxide. - 2015. - Vol. 48. - P. 44-50.

10. Oxidative Stress in Hypertension: Mechanisms and Therapeutic Opportunities / R. Brito, G. Castillo, J. González [et al.] // Exp. Clin. Endocrinol. Diabetes. - 2015. Vol. 123, № 6. - P. 325-335.

\section{ПРИМЕНЕНИЕ ДОНАТОРОВ ОКСИДА АЗОТА В УСЛОВИЯХ СОЧЕТАНИЯ ГИПЕРТОНИЧЕСКОЙ БОЛЕЗНИ И САХАРНОГО ДИАБЕТА 2-ГО ТИПА С ОЦЕНКОЙ ПАРАМЕТРОВ ТРОМБОЦИТАРНОЙ АГРЕГАЦИИ}

\section{Е.И. Шориков}

Резюме. Статья посвящена изучению агрегационных свойств тромбоцитов у больных гипертонической болезнью в сочетании с сахарным диабетом 2-го типа при добавлении к базисному лечению донатора оксида азота Lаргинина. Проведено открытое проспективное исследование с включением 191 пациента. Установлено достоверно более существенное снижение параметров спонтанной агрегации в группе, которая получала L-аргинин дополнительно к базисному лечению. Использование донатора оксида азота на фоне базисной терапии сопровождалось достоверно бо́льшим удлинением времени АДФ-индуцируемой и адреналин-стимулированной агрегации, а также более значительному снижению степени АДФ- и колаген-индуцируемой агрегации в сравнении с применением стандартного антигипертензивного лечения.

Ключевые слова: гипертоническая болезнь, сахарный диабет, агрегация тромбоцитов, донатор оксида азота, L-аргинин.

\section{APPLICATION OF NITRIC OXIDE DONORS IN PATIENTS WITH HYPERTENSION COMBINED WITH DIABETES MELLITUS TYPE 2 BY ASSESSING PARAMETERS OF THE PLATELET AGGREGATION}

\section{E.I. Shorikov}

Abstract. The paper presents a study of platelet aggregation in patients with hypertension combined with type 2 diabetes when the donor nitric oxide L-arginine is added to the basic treatment. We have conducted an open prospective study including 191 patients. It was found significantly more substantial reduction in the parameters of spontaneous aggregation in the group that received L-arginine in addition to the basic treatment. Using donor nitric oxide in the basic therapy was accompanied by significantly greater lengthening the time of ADP-induced and adrenaline-stimulated aggregation, as well as a significant reduction in the degree of ADP and collagen-induced aggregation compared with standard antihypertensive therapy.

Key words: hypertension, diabetes mellitus, platelet aggregation, nitric oxide, L-arginine.

Higher State Educational Institution of Ukraine «Bukovinian State Medical University» (Chernivtsi)

Рецензент - проф. Т.О. Ілащук

Buk. Med. Herald. - 2016. - Vol. 20, № 1 (77). - P. 184-187

Надійшла до редакції 25.11.2015 року

(C) Є.І. Шоріков, 2016 